\title{
The Threat of Danger: Decadence and Vittiv
}

Miguel Morgado

Instituto de Estudos Políticos da Universidade Católica de Lisboa

\section{Resumo}

A decadência e a protecção da civilização são temas recorrentes no pensamento de Raymond Aron. Em particular, no final da sua carreira, Aron reflectiu acerca da condição do mundo ocidental e no significado da palavra "decadência". A este respeito, Aron achou o trabalho de Maquiavel extremamente útil, ao ponto de igualar a decadência com a falta do que Maquiavel nomeou virtú, ou "vitalidade histórica". Este paper tenta examinar o conceito Maquiavélico de virtú, de forma a compreender a noção de Aron de decadência e em que aspecto se pode falar "de Europa decadente". A decadência é um problema sobretudo político; logo, envolve uma reflexão detalhada no questionamento político bem como nas obrigações, limites e fins da acção política enquanto tal. A decadência torna-se mais transparente quando se considera o relacionamento entre, por um lado, civilização e liberdade, e por outro, a ameaça do perigo. Este paper tenta também dirigir-se a algumas das causas da decadência europeia identificadas por Aron.

\begin{abstract}
Decadence and the protection of civilization are recurring themes in Raymond Aron's thought. In particular, at the end of his career Aron reflected on the condition of the Western world and on the meaning of the word "decadence". In this regard, Aron found Machiavelli's work to be immensely helpful, to the point of equating decadence with the lack of what Machiavelli named virtù, or "historical vitality". This paper tries to examine Machiavelli's concept of virtù in order to understand Aron's notion of decadence and in what regard one can speak of "decadent Europe". Decadence is a thoroughly political problem; therefore it involves a comprehensive reflection on the question of the political as well as on the demands, limits, and ends of political action as such. Decadence becomes more transparent when one considers the relationship between, on the one hand, civilization and liberty, and on the other, the threat of danger. This paper also tries to address some of the causes of European decadence as they were identified by Aron.
\end{abstract}

\footnotetext{
* Intervenção proferida no âmbito da Conferência Internacional "Raymond Aron. Um Intelectual Comprometido", que decorreu no IDN, Lisboa em 14 e 15 de Abril de 2005.
} 
More congruent with the facts is to think that there is no safe progress, no evolution, without the threat of involution and retrogression. Everything, everything is possible in history both triumphal and indefinite progress and periodic retrogression. For life, individual or collective, personal or historical, is the only entity in the universe whose substance is danger. Life is composed of incidents. It is, rigorously speaking, drama.

Ortega y Gasset ${ }^{1}$

Raymond Aron was one among several thinkers who have been noticed for their awareness (in the case of Aron, a melancholy awareness) of the frailty of what we can call "civilization". Today we might be suspicious of the relevance of such a word, "civilization". What is "civilization"? In the words of a great contemporary of Aron, "the term civilization designates at once the process of making man a citizen, and not a slave; an inhabitant of cities, and not a rustic; a lover of peace, and not of war; a polite being, and not a ruffian"; it is the "conscious culture of humanity, that is to say, what makes a human being a human being". Essentially, "civilization" is the "conscious culture of reason". Therefore, the "twin pillars" of "civilization" are theoretical and practical reason or "morality" and "science"2. "Civilization", then, seems worthy of protection; it seems to be the good which allows the enjoyment of all remaining goods. It seems to be another word for the conditions which allow the good life. Aron could add that, consequently, one of civilization's main elements is freedom, namely "the freedoms we enjoy in the West". Liberal and democratic freedoms, or Western freedoms, are indeed "humanity's most precious" "acquisitions"; but they are also their most "tenuous" acquisitions ${ }^{3}$. Threatened by dangers never completely eliminated, "civilization", which shelters and protects man, depends on constant care, and on an always realistic disposition. Confronting reality means to understand that human solutions to human problems, whether one means the "technical" problem, the "political" problem or the "economic" problem, are always imperfect and provisional. More

1 La rebelión de las masas, (Madrid: Alianza Editorial, 1995), p. 102.

2 Leo Strauss, "German Nihilism", Interpretation, Spring 1999, vol. 26, no. 3, p. 365.

3 Cf. In Defense of Decadent Europe, Stephen Cox (trans.), (New Brunswick: Transaction Publishers, 1996), p. xxviii. 
often than not, those solutions incorporate in themselves more or less unstable contradictions, something that sooner or later becomes a threat to the institutions that represented what was thought to be the definitive solution. The forgetfulness of danger (to use in my own way a very famous expression) or the forgetfulness of threat as such may be due to excessive confidence, to anomic apathy, or to a process of devaluation of civilizational structures (what someone like Ortega y Gasset would call "ingratitude" ${ }^{\prime \prime}$ ), which in turn can be put in motion by traumatic experiences or by waves of bad conscience. But whatever its origin or psychological explanation, politically speaking, the forgetfulness of danger is always a synonym for crisis. Aron liked to quote (his once teacher) Alain: "civilization is a thin film that can be torn apart by a single blow; and barbarism enters through the breach" ${ }^{\prime \prime}$. In this regard, historical experience is a precious teacher: "those who lived in the time of Hitler and Stalin know that the worst is always possible" ${ }^{\prime \prime}$. One of the main lessons of the events of May, 1968, was precisely the "fragility of the modern order". All societies, whether "pluralist" or "non-pluralist", "incorporate elements of weakness" ${ }^{\prime \prime}$. Civilization requires care, it resists ingratitude only with great difficulty and it dies at the hands of contempt. Above all, without "historical vitality", that is, without the ability and will to identify and accept the inevitability of the enemy ${ }^{8}$, political regimes, namely the moderate ones, put their survival at risk.

In this regard, Aron's comments on Alain are noteworthy, for they indicate the spirit of the "eternal left". Alain, said Aron, represented the "eternal left", that is "the left that never holds power, since it is defined by the resistance to power, which by its very essence leads to abuses and corrupts those who hold it" ${ }^{\prime \prime}$. Of course Aron would never admit (nor would any intelligent person for that matter) that the forgetfulness of danger is a fault monopolized by the left. But the comment on Alain and the spirit of the "eternal left" can be read as saying that the latter fears (and denounces) power as such. Now, danger has to be met, not exclusively, but nevertheless unavoidably, with the use of power. Or to put it more rigorously: danger has to be met with the readiness to use power. It has to be said that Aron was not blind to the misuses of power. On the very contrary, he spoke very eloquently on the misuses of power even by the most

4 La rebelión de las masas, p. 86.

5 Memoirs. Fifty Years of Political Reflection, George Holoch (trans.), (New York: Holmes and Meier, 1990), p. 452.

6 In Defense of Decadent Europe, pp. xxvii-xxviii.

7 La révolution introuvable. Réflexions sur les événements de Mai, (Paris: Fayard, 1968), pp. 15, 45.

8 Cf. Daniel Mahoney, Introduction to the Transaction edition, In Defense of Decadent Europe, p. ix.

9 Memoirs, p. 29. 
well-intentioned of men. He condemned the misuse of power whenever he had the chance to do so. However, Aron knew that politics implies the use of power. Political existence as such implies the use of power against enemies. An important part of Max Weber's ethics of responsibility, which Aron took very seriously, said that the dictum "do not resist evil by force" had to be refused as apolitical. The responsible statesman must say instead "you should resist evil by force, otherwise you are responsible for its triumph"10, or, as Machiavelli would say, "an evil should never be allowed to persist out of consideration for a good if that good can easily be overwhelmed by that evil"11. For evil will not simply go away. As the French historian-statesman François Guizot taught: "To see what is, is the first and excellent character of the political spirit" ${ }^{\prime \prime}$. The amount of good and evil in the world does not change according to our dreams. Evil has to be fought by the word and, unfortunately, sometimes by the sword. The fight against evil must be balanced, on the one hand, by the knowledge that "antagonisms" will never be eliminated, and, on the other hand, by the belief that the worst is possible, but "not always certain". Some readers of Aron may suspect the use of the word "evil" here. After all, Aron argued that "politics is never a conflict between good and evil". However, by saying that "politics is never a conflict between good and evil", Aron did not mean that politics is outright immoral or that morality is radically separated from politics. He was arguing that political conflict is never about "pure" causes, but rather that political battles are "equivocal". Because politics, and especially foreign policy, is always a conflict, elements of immorality inevitably creep in. "Pure" causes in politics must compromise with reality. Thus, politics becomes a "choice between the preferable and the detestable". But the distinction between the "preferable" and the "detestable", although it is in part contingent, is solidly based on what is evil and what is not. One could say, like Hobbes, that although the summum bonum is (metaphysically, epistemologically, and politically speaking) something enclosed by great difficulties, one can at least agree on what the summum malum is. The basis for our knowing what in the concrete situation is "preferable" and what is "detestable" is not arbitrary, neither is it a question of pure convenience. This is what it means to "think and act politically"13.

10 Cf. Max Weber, Le Savant et le Politique, Raymond Aron (ed.), (Paris: Librairie Plon, 1959), p. 170. Note the example of the "pacifist" described by Weber.

11 Machiavelli, Discorsi, III.3.

12 Francois Guizot, La démocratie en France, (Paris: Victor Masson, 1849), p. 142.

13 Thinking Politically. A Liberal in the Age of Ideology, James McIntosh, Marie McIntosh (trans.), (New Brunswick: Transaction Publishers, 1997), pp. 242-243. 
During the Cold War, Aron reflected on the situation of Europe and he started by questioning the adequacy of the words "decline" and "decadence" to describe it. "Decline" is more, let us say, value-neutra ${ }^{14}$. It seems to limit itself to coldly record a reduction in relative power or a reduction of the "contribution of a collectivity to the great works of humanity". "Decline" is a concept that can be submitted to quantitative determinations. During the Cold War one could argue that Western Europe was "declining", but one could also plausibly argue that it was not "declining". For example, in the 1970's, from the point of view of demography or military strength, Western Europe was unquestionably declining. But "decline" was by no means evident from the point of view of economic prosperity. From the 1950's to the 1970's Western Europe could show better economic statistics than the United States, not to mention the rest of the world, especially the communist bloc and the Third World. One could say that indeed until the beginning of the 1980's it was usual to speak of American decline in comparison to (yes) Europe and Japan and Southeast Asia. As a concept, "decline" is not useless, but it seems to fail to capture the reality of Europe. As a concept, "decline" is "entirely relative"15. Another term that could be applied is, of course, "decadence". What is "decadence"? Instead of giving a ready answer, Aron preferred to resort to Machiavelli, one of the thinkers par excellence of "decadence" and "rebirth". To the question "what is decadence?", Aron replied: "Machiavelli would have answered: the loss of virtù, or the loss of historical vitality". "Decadence" means, therefore, a loss of virtù or historical vitality. Machiavellian virtù, according to Aron, means "the capacity for collective action and historic vitality"; indeed, virtù is "the ultimate cause of the fortune of nations and of their rise and fall"16. Thinking of England at the end of the 1970's, Aron understood "decadence" to imply "the inability of a nation to shake off its indolence" ${ }^{\prime 17}$. "Decadence", in contradistinction to "decline", involves strong value-judgments.

At the very end of In Defense of Decadent Europe Aron concluded: "But rejecting servitude is not enough: one must also recognize the dangers, and face up to them $^{\prime \prime 18}$. Some may say that Aron was merely referring to the Red Army's divisions ready to assault Western Europe. And, of course, he was. But the sentence has a

14 Cf. In Defense of Decadent Europe, p. xxv.

15 Memoirs, p. 424.

16 In Defense of Decadent Europe, p. xxvii.

17 Memoirs, p. 424.

18 In Defense of Decadent Europe, p. 263. 
universal content; it is a general reflection typical of a political philosopher. Notice that Aron emphasized the need to recognize danger and the will (as well as the ability) to stand up to it. When Aron was asked if there still existed "collective resolution" in Europe, he replied straightforwardly: "no longer"19. The crisis of Europe is many-faced and complex, but one of its elements is, according to Aron, its loss of "collective resolution", of "historical vitality", of awareness of danger, of readiness to face up to danger; in a word, Europe lacks virtù. It might sound strange to us Europeans, who take pride in having been cured of Machiavellianism, as Montesquieu would say ${ }^{20}$, to learn that we suffer from a lack of Machiavellianism.

But to mention Machiavellianism is one thing; to face Machiavelli's thought may be another. Aron never mistook Machiavelli's complex and open-ended thought for "vulgar" Machiavellianism, which is the doctrine taken from his writings by Machiavelli's "unfaithful disciples". Even if one wishes to refer to Machiavellianism there is still an intelligible and moral difference between a "civilized Machiavellianism" and the "vulgar disciples of Machiavelli" 21 . Since the sixteenth-century, "vulgar" Machiavellianism has been enjoying a successful career in Europe. It has been used to promote a conception of politics which claims a necessary distinction between leaders and masses, reveals contempt for the people, allows the people only passive obedience, and produces power as the sole end of every means available to the ruler(s). It affirms the right to rule in favour, not of those who are intellectually or morally superior, but of those who have a superior "capacity for violence". As its first impulse comes to be felt, "vulgar" Machiavellianism stands for "indifference towards spiritual values"; but with the realization of its full consequences, it proclaims an outright reversal of the "traditional scale of values". Underlying its conception of politics, there is a conception of history without "meaning" or "end", driven only by force. Force in history manifests itself through the mortal struggle between men, and "above all between peoples". In practical terms "vulgar" Machiavellianism in nothing more than a "technique of power" at the service of internal domination, but also of "imperial conquest". In other words, "vulgar" Machiavellianism has been used as a legitimizing theory of tyranny. As imperial tyrannies, communism, national-socialism, and fascism, may be seen as obvious heirs of "vulgar" Machiavellians.

19 Thinking Politically, p. 245.

20 Cf. De l'Esprit des Lois, XXI.20.

21 Machiavel et les tyrannies modernes, (Paris: Éditions de Fallois, 1993, pp. 60-61; Peace and War. A Theory of International Relations, (New Brunswick: Transaction Publishers, 2003), pp. 298, 609. 
Although Aron knew perfectly well that one must separate Machiavelli's thought from what his "vulgar" disciples took from it, he was not blind to the fact that the "classical answer" to "vulgar" Machiavellianism is insufficient. It is not enough to answer that "the technique of tyranny is not equivalent to the eulogy of tyranny". One does not solve Machiavelli's ambiguities, nor does one understand his strange inheritance, by stating this "logically indisputable" but unsatisfactory answer ${ }^{22}$. It cannot be denied that Machiavelli himself wrote, not exclusively, but nevertheless intentionally, for tyrants. Every reader of Machiavelli knows that to be an "adviser of the Prince" is to be an adviser also of tyrants ${ }^{23}$. The free republic won Machiavelli's preference, but the necessity of tyranny in politics is considered to be unavoidable, especially when legitimacy becomes a nebulous notion. Twentieth-century's enemies of freedom may be called "Machiavellians" for they inherited what Aron called a Machiavellian "attitude", that is, they "spontaneously conceive[d] politics upon a Machiavellian mode" ${ }^{24}$. But they were the children of extremist - and also "vulgar" Machiavellianism. There is another way of learning with Machiavelli and thereby acquiring a deep sense of political reality: a way that presupposes a critical reading of Machiavelli, rendering the Florentine philosopher's teachings more moderate or "civilized". There is consequently a moderate or "civilized" Machiavellianism, in contradistinction to an extremist and "vulgar" Machiavellianism, which generates important insights concerning the political world, not to mention the protection against "illusions" and thus against prophetism²5.

The difference between "absolute" Machiavellianism and "moderate" Machiavellianism became the main point of Aron's critique of Jacques Maritain's politics. In the End of Machiavellianism Maritain had argued, for several reasons (both moral and political), for the end of every form of Machiavellianism. Aron agreed that "absolute" Machiavellianism, with its emphasis on the quest for power as the sole objective of politics, leads to the idolatry of the state, which inevitably produces the unlimited state and, as a result, the violation of individual rights. "Absolute" Machiavellianism,

22 Machiavel et les tyrannies modernes, pp. 72, 120, 121, 75.

23 Cf. "Machiavel et Marx" in Machiavel et les tyrannies modernes, p. 262.

24 [René Avord], "Le Machiavélisme, doctrine des tyrannies modernes" in Machiavel et les tyrannies modernes, p. 194.

25 See "Machiavel et Marx", p. 273. Aron also denounced the tendency of Machiavellian "pessimism" for giving in to the "temptations of conservatism", as well as its propensity for constructing a base image of man incompatible with his essential dignity. 
said Aron agreeing with Maritain, is not able to stand without collapsing into a sort of nihilism which denies every form of reality that is not recognized as a condition of power or as an object of power. It opens the door to a fury of violence and declares all wars to be wars of extermination or, in the conditions of modern society, total wars ${ }^{26}$. But this specific agreement with Maritain's vision of politics did not prevent Aron from criticizing the former's "naïve optimism" regarding the practical realities of rule. It is naïve to expect that a statesman's responsibility towards his community can be fulfilled without resorting to some dubious methods. The good intention of rejecting Machiavellianism is not enough for the statesman who will never have "a free choice of means". The fundamental conditions of political action, as well as human nature's imperfection, combine to deny eternal coherence between efficacy, on the one hand, and moral imperatives, on the other. It is impossible to apply a general moral rule regarding the use of dubious political means. The determination of what separates legitimate from illegitimate force, legitimate from illegitimate deception, depends on the "analysis of particular cases", through a "sort of casuistry of political morality" 27. It could be argued that the need for determining such delicate borderline only comes out in full force in "extreme situations"; "normal" political life does not evolve around "necessary evils". Aron would agree. But he would point to the sad fact that it is "very difficult to find moments where there are no extreme situations". Furthermore, he would note that to accept the different demands of "extreme" and "normal" situations, regardless of their relative frequency, is tantamount to accepting at least the occasional need for "moderate" Machiavellianism. It is to "moderate" Machiavellianism that the responsible statesman turns to whenever the "extreme" situation arises. The responsible statesman strives to uphold "peace and the good", but he "cannot forget the permanent risk, the risk of destruction" ${ }^{\prime 28}$.

26 Aron acknowledged that Machiavelli's thought was directly responsible for some of the traits exhibited by "absolute" or extremist Machiavellianism. In particular, Aron was very critical of a philosophy which does not recognize ulterior dimensions of human life other than the political. In Machiavelli's theory "what is essential is not only the amoral consideration of political means, nor the open suggestion of the necessity of immoral means, but the extension of pragmatism to the whole of human reality, thereby reduced to the status of means. Means in view of what? Of the social order, in itself a means of power. But this power of states, towards what does it tend? Having no other end besides itself, does not politics become meaningless?" (Machiavel et les tyrannies modernes, p. 82).

27 [René Avrond], "La querelle du Machiavélisme", pp. 391-392.

28 "Sur le Machiavélisme: Dialogue avec Jacques Maritain" in Machiavel et les tyrannies modernes, pp. 430$-435$. 
Accepting the priority of the common good is indisputable, as long as it is also accepted that power is an "indispensable condition" of the actualization of the common good. Given the conditions of political action, one must face the necessity of the acquisition of power, as a subordinate end, that is to say, subordinate to the ultimate end, the common good of the community. However, the acquisition of power and its exercise call for different political methods in comparison to the political task of creating a just society. Aron knew that the contradiction between the "quality of means" and moral ends is not without risks. "Too often, cynicism at the service of the ideal degenerates in pure and simple cynicism". This possibility is not to be underestimated, but it does not change the reality of man's political existence, which never loses its dramatic or tragic character. And yet, this is what gives political life its "sombre greatness": statesmen act often with the use of means they detest because "they believe themselves to be, in their soul and conscience, responsible for the common destiny"29. Perhaps this is what it means to be a "liberal disciple" of Machiavelli ${ }^{30}$.

With these qualifications in mind, let us, then, accept Aron's invitation to read Machiavelli and let us take seriously the diagnosis of Europe as having little or no virtù.

Machiavelli's virtù can be examined through several angles. But I do not wish to go through all of them; that would take me too far. Nevertheless, let me try to offer an analysis of Machiavelli's virtù relevant enough to understand Aron's comment on Europe. Machiavelli became famous, among other reasons, for radically distinguishing goodness (bontà) from virtue (virtù). According to Machiavelli, something is called "good" if it is done out of a benevolent, altruistic, and "pure" intention, regardless of what the final outcome is. A "good" deed is done out of concern with moral symmetry between means and ends. To be considered "good" a man must not compromise his ends with dubious means. He must abstract, as it were, from the imperatives of efficacy. To the "good" man, the good is always the most useful and the most convenient. It is only the "bad" man who separates those categories, and then chooses convenience over "goodness". But as Machiavelli put it "there is such a gap between how one lives and how one ought to live that anyone who abandons what is done for what ought to be done learns his ruin rather than his preservation: for a man who wishes to profess

29 [René Avrond], "La querelle du Machiavélisme”, pp. 394-395.

30 See "Machiavel et Marx", p. 267. 
goodness at all times will come to ruin among so many who are not good. Hence it is necessary for a prince who wishes to preserve himself to learn how not to be good, and to use this knowledge or not to use it according to necessity"31. The reality of necessity is incompatible with constant and universal "goodness". In the world of necessity to abide by the rules of goodness is to invite disaster. It is the "human condition" itself which forbids that one lives by all the good qualities that the life of goodness demands. In Machiavelli's work, in order to think politically, one "must presuppose that all men are evil and always prone to exercise the malice in their minds whenever opportunity gives them free rein" ${ }^{32}$. In the world of necessity something more adequate and fierce than goodness is necessary. Virtù is necessary as a way to respond affirmatively to necessity. I think I shall not be very far from the truth if I say that, to Machiavelli, "necessity" may be understood as another word for danger. But perhaps it is safer to say that necessity does not arise without danger ${ }^{33}$. For Machiavelli, virtù is the only adequate response to danger. Either danger is opposed by virtù or it brings servitude and destruction.

Virtù is a sort of practical wisdom, or, to avoid confusion, of political wisdom. It is a quality of action. It is in acting that one shows one's virtù. But if Machiavelli used the word virtù to denote political wisdom in action, then one is forced to conclude that it includes not only proud and brave action, but also deceitful action. Virtuous "princes" are those who can be both the "lion" and the "fox". Whether one should be either the "lion" or the "fox" depends on circumstances. But in order to understand if circumstances demand one or the other animal the ability to read circumstances correctly is required. Virtù, then, provides also a hermeneutics of reality. Virtuous princes recognize their occasion or opportunity. Virtù is the ability to know the times we live in, to know its opportunities and dangers. Virtù not only allows one to correctly see opportunities and dangers but it is also that creative energy (or "vitality") one needs in order to respond to opportunities and dangers ${ }^{34}$. But virtù, it has to be said, is neither fury nor war-mongering; it is only the acceptance of war, and of war-like virtues, when there is no other alternative to war. Fury is disproportionate, irrational, unambiguously violent, sterile, blind, and barbaric; virtù is disciplined, balanced, reasonable, fecund, mindful of consequences, and prudent ${ }^{35}$.

31 Machiavelli, Il Príncipe, XV.

32 Machiavelli, Discorsi, I.3.

33 Discorsi, I.2.

34 Il Principe, XVIII, VI; Discorsi, II.13, 29.

35 Cf. Discorsi, III.36. 
Nevertheless, if danger is, by definition, violent and menacing, and if virtù is the only adequate response to danger, then virtù is also a disposition for violence, or, rather, for disciplined violence.

Neither of us knows what Machiavelli would have said about contemporary Europe for Machiavelli is not alive. But we all know that Aron regretted contemporary Europe's lack of virtù. Is it at least probable that Machiavelli would agree with Aron? No one can give a definitive answer. But we do know what Machiavelli said about the disgraced Piero Soderini. In fact the portrait of Soderini made by Machiavelli captures some of the traits that may be associated with a Europe without virtù: "[Soderini] believed that with time, goodness, his good fortune, and benefits to some, he could eliminate envy; (...) he believed that he could overcome those remaining men who opposed him out of envy without any disturbances, violence, and uproar. He did not know that time waits for no one, goodness is not enough, fortune changes, and ill will finds no gift that will placate it"36.

In a certain sense, it may be said that Americans today, at the beginning of the twenty-first century, agree with Aron in criticizing Europe's loss of "historical vitality". Indeed, it appears to be one of the great differences between America and Europe. This disparity among members of the same civilization is a remarkable fact, since Aron himself, in the 1970's, was becoming increasingly apprehensive for America's own loss of "historical vitality". Aron asked: "Faced with an increasingly powerful and militant Soviet Union, do the Americans still have the same resolution they did thirty years ago?" ${ }^{\prime 37}$ In the 1970's both Europe and America seemed to be on the path of "decadence", although in different degrees. This means that in the last thirty years great changes occurred in America, if not in Europe. Europe, both the "Old" and the "New", still stands for more or less the same abstract principles that America also shares; both have more or less the same strategic interests. That is why, in spite of everything, America and Europe are still allies, not enemies. But Americans tend to see Europeans, at least the "Old" Europeans, as lacking in virtù, or in resolve to act. If one looks at both sides of the Atlantic dispassionately, it is easily noticed that American self-confidence in what respects the willingness and ability to rise up to the challenge of its enemies is in much better shape than Europe's. One sees the virtue of patriotism being cultivated in America in a way that astonishes many Europeans. But

36 Discorsi, III.30. See also, III.3.

37 In Defense of Decadent Europe, preface to the American edition, p. xix. 
patriotism is precisely that quality which makes concrete citizens out of men. Patriotism deepens the distinction between the citizen and the stranger, especially if the stranger is identified as an enemy. It is in need when the occasion for collective action arises and when sacrifices are demanded. Patriotism is one of those "ideas or prejudices that hold a community together"; it cannot lose its strength without undermining the "capacity for collective action" ${ }^{38}$. On the other hand, Europeans tend to denounce America's so-called virtù as plain hybris bred by excessive power. Europeans tend to see America's self-assertion, not as a sign of "historical vitality" - which would be tantamount to admitting their own inferiority - but as a dangerous form of collective selfishness coupled with an incomprehensible thirst for power. To Europeans, patriotism is much more ambivalent a virtue than it would appear to Americans. Be that as it may, it is difficult not to recognize that Europe wishes to dismiss the need for virtù in a way that America does not. In this particular sense, it may be said that America of today is better prepared than Europe to fight off "decadence".

The loss of "historical vitality" has an immediate political consequence, which is the loss of resoluteness, or the ability to choose decidedly. According to Machiavelli, "the worst quality that republics have is irresoluteness, so whatever course of action they take, they do of necessity; and any good that happens to be done to them they do out of necessity and not out of their wisdom" ${ }^{\prime \prime 3}$. In politics, as in life, there is no such thing as a non-choice; even when we refuse to choose we are already choosing. But Machiavelli was trying to warn us that the tendency to not choosing, or delaying choice until there is no alternative, is fatal. Sometimes we hate the exclusiveness of a given choice, that is, the fact that by deciding on a given course of action one excludes other possible courses of action. In this case, according to Machiavelli, the worst to be done is to try to have it both ways, that is, to try to come up with an irresolute course of action which apparently does not exclude other ends. But to decide thus is just another manifestation of irresoluteness. One recalls Aron's admonition of Europe's policy during the 1970's of remaining America's allies and engaging the Soviet Union in a friendly relationship. One could say in a Machiavellian way that Europe's policy could only incur the suspicion of its ally and the scorn of its enemy; the former was beginning to lose its trust and the latter would never feel respect towards countries in which a structural weakness could be detected ${ }^{40}$. Decisions of this sort, Machiavelli would say, "arise either from

38 Memoirs, p. 423.

39 Machiavelli, Discorsi, I.38.

40 Compare Discorsi, II.14. 
weakness of courage and armed forces or from the ill will of those who have to decide" ${ }^{\prime \prime}$.

Machiavelli famously recommended a remedy for the "renewal" of political communities threatened by "decadence". According to him, a republic "has to be taken back frequently towards its beginnings/principles". Machiavelli wished to indicate the need for a polity to be taken back toward its "origins" in order to accomplish its own renewal. To be taken back to its "origins" or "beginnings/ / principles" means to remember the good things incorporated in each polity at its "origins", and that became inscribed as "principles", and then re-enact that remembrance. Moreover, Machiavelli emphasized that, in order to fight off "corruption" or "decadence", the return to the principio must mean the regaining of the awareness of danger. Because the memory of danger dies out, it has to be recovered politically. Otherwise, forgetful men will become "idle" $\mathrm{men}^{42}$. Does contemporary Europe need to be taken back toward its principio in order to regain "historical vitality" or virtù? America, it seems, is more willing to be periodically taken back to its principio, namely to the principles of its Founding. But Europe is more ambivalent toward its past, among other reasons because its past is much more ambivalent than America's. According to this Machiavellian rationale, contemporary America seems to retain more easily its capacity for "renewal" than Europe. Europeans are more ambivalent than Americans in what regards the things worthy of being remembered and "renewed". But Machiavelli makes Europeans despair, for in order to proceed to a return to its principio a community, or at least some of its citizens, must already possess some virtù. So Europe seems to be trapped between its lack of virtù and the lack of will and ability to overcome its loss of virtù. Because Europe lacks virtù it has little or no "historical vitality", and, at the same time and for the same reason, it denies itself the remedies to regain "historical vitality".

For many people, the loss of virtù may seem no great loss; it may even appear to be a sign of moral "progress". After all, we all have renounced heroic politics for a long time. Aron, a thinker of impeccable liberal and democratic credentials, knew that democracy is the only regime that "confesses", or rather, that "proclaims that the history of states is and ought to be written not in verse but in prose" ${ }^{\prime \prime 3}$. In Aron's

41 Discorsi, II.15.

42 Discorsi, III.1, 22. The Italian word principio is somewhat ambiguous.

43 Introduction to Max Weber, Le Savant et le Politique, p. 23. 
thought, this liberal-democratic trait is an immeasurably precious antidote against lyrical or literary politics. It is an important element of soberness in politics, which is a realm of human activity where the interference of "poetry" and "lyrical exaltations" necessarily generates catastrophic effects. But, as Aron argued so many times, liberal-democratic politics is always threatened. The freedoms which our civilization proudly claims need to be defended in order for them to be enjoyed. Freedom needs virtù. However, Europe in the 1970's was "reduced to the enjoyment of its own well-being and freedoms", since it was "incapable of defending itself" and had "no great plan in common". Above all, Europe (and also America) was described as a "hedonistic" society, that is, a society of "self-centered enjoyment". In this sense, "hedonistic" society is a society whereby individuals devote themselves completely to the private enjoyment of their pleasures and pursue their own conceptions of happiness. But because such a society tends to become obsessed with the present moment and "loses interest in the future", Aron thought that it thereby "condemns itself to death". In spite of being the motherland of historicism, Europe seems to live in what could be called an "eternal present": it feels uncomfortable with its past and stands in an indifferent relationship with its future. Ironically, Europe's common consciousness is averse to historical reason whenever it has to face its most urgent challenges. The life in the "eternal present" becomes more fully revealed as the life of the individual enclosed in himself or, in other words, the self-sufficient life in the pursuit of one's incommensurable conception of happiness. Lost in the absolute moment of the present, Europe asks of someone who questions its capacity for renewal: what do we have to supply us with the resources necessary for renewal? What is there to renew? In view of what should this putative renewal be accomplished? These questions become transparent only from the point of view of historical reason. But historical reason is contradictory with life entrenched in the "eternal present". Hence, the questions remain unanswered. Moreover, they risk becoming unintelligible. A total morality of pleasure and individual happiness, with no regard for "civic virtues" puts, in Aron's words, "survival in doubt" 44 . Thus understood, "hedonistic" life seems to play the same role in Aron's concerns as "idleness" plays in Machiavelli's thought. "Idleness" is the condition of men who are incapable of virtù. An easy life without some political effort to create habits of sacrifice and duty breeds "idleness". In order to balance the tendency for "idleness" generated by too easy circumstances,

44 In Defense of Decadent Europe, pp. xx, 251; Thinking Politically, p. 247. 
other set of circumstances have to be politically created in order to counter those malign effects ${ }^{45}$. "Idle" men are effeminate men; they are easy prey to enemies and tyrants ${ }^{46}$.

Virtù is the opposite of "idleness". Whereas "idleness" makes men weak, virtù makes them good defenders of freedom. "Idleness", then, makes the defense of freedom impossible ${ }^{47}$. And this is precisely Aron's point. A radically individualistic and hedonistic society not only makes increasingly painful the acceptance of "civic virtues", but it creates a strongly apolitical environment for human existence. Civic duties, which imply some sacrifice of self-centered enjoyment of private pleasures, are a reminder that man is also a citizen, and that he must be "ready to fight in order to conserve the opportunity to enjoy their pleasures and their happiness". "Civic virtues", "civic duties", and "civic traditions" are an indispensable moral equipment to allow men to become genuine citizens. They are part and parcel of the psychological and moral conditions "required to safeguard the chances for the pursuit of happiness so passionately desired by everyone". Europe risks becoming, not a political community, which presupposes an understanding of what is common, which presupposes a common good pursued through some form of "collective action", but a collection of private individuals bearers of rights with no duties attached besides the obvious one of paying high taxes. If Europe, said Aron, had become a radically "hedonistic" and "individualistic" society, then "we are both brilliant and decadent" 48 . Either "hedonistic" society integrates some measure of "civic" consciousness, which is a way of referring to the assimilation of the perception of danger, or it will fall. As Machiavelli said, "a people completely permeated by corruption cannot live free at all" ${ }^{\prime 9}$. In other words, a decadent people cannot defend its freedoms for very long. Even the Romans in the end "grew sure of their freedom and thought they no longer had any enemies to fear" ${ }^{\prime \prime 2}$.

As I have mentioned, many people will not regret the loss of virtù. They will consider that it is Europe's sole moral triumph to live according to other principles or standards. Some Europeans may believe that to think exclusively in terms of "human rights" and "equality" is enough in order to think politically. But that would be their

45 Machiavelli, Discorsi, I.1, 3.

46 Discorsi, I.6.

47 Discorsi, II.2.

48 Thinking Politically, p. 247.

49 Machiavelli, Discorsi, I.16.

50 Discorsi, I.18. 
mistake: one should not, like Léon Blum before the Second World War, "confuse an abdication with the sign of a new world" ${ }^{\prime 5}$. In the conditions of modern democracy, obsession with equality is not only "contrary to the survival of a liberal-spirited society", but it is also conducive to hostility to the political order as such ${ }^{52}$. This passion for equality is strengthened by an intellectual vogue that seems to be a reaction to "the madness of Hitler's racism". As an ideology, it is an extreme response to political extremism of a different variety. In our times, the voice of extreme equality rises up against the brute ideology of extreme inequality. As ideologies, both are blind in the face of constant facts. In the case of the ideology of equality one witnesses the "forgetting that the inequality of individual gifts is the least contestable of all facts" ${ }^{25}$. The obsession with equality forgets that in modern society the relation between equality and hierarchy is dialectic. Modern society puts itself under two great imperatives: to maximize production and to accomplish equality among individuals. Equality is the "supreme norm", but the other purpose of conquering and mastering nature renews the need for hierarchy and discipline. On the other hand, modern society is still a political society. Now, the political problem is founded on "two constant facts": the physical and intellectual inequality among individuals and the

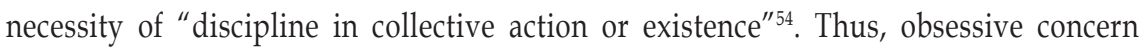
with equality is a form of (conscious or unconscious) denial of the conditions for the accomplishment of the tasks that modern democratic - that is, egalitarian - society sets for itself. But because some of those conditions are common to all decent political orders, one may say that the obsession with equality goes against the grain not only of modern society's demands, but also of every political community.

But there is another obsession shared by both Americans and Europeans: the obsession of "the need to defend human rights". Aron read this obsession as another means to stop thinking politically, as a way to avoid the political, to escape from it. To think solely in terms of human rights is to avoid the typical political reasoning of examining which political regime best protects human rights ${ }^{55}$. To think solely in terms of human rights is an expression of that desire for immediacy so dear to modern

51 Memoirs, p. 98.

52 In Defense of Decadent Europe, p. 246.

53 Peace and War, p. 753.

54 Cf. Les désillusions du progrès. Essai sur la dialectique de la modernité, (Paris: Gallimard, 1969), pp. xxiii, 21, 14, 10.

55 Thinking Politically, pp. 241-243. 
democratic societies. On this particular subject, Pierre Manent has been one of the most profound writers. It is probably no coincidence that he was also a student of Aron's. According to Manent, the reigning understanding of equality and human rights in modern democracy makes the political order resemble the state of nature. If we take what the several conceptions of the state of nature had in common, we conclude that the state of nature can be defined by a "state of independence, freedom, and equality". But modern democratic man wants to be independent, free, and equal. He desires the "immediacy of experience", or to put it more rigorously, he desires the immediacy of his particular, individual experience. He wants to be free and equal in order to be able to live the experiences of his particularity with the minimum amount of mediation. Modern democratic society seems to exist solely to protect this individual desire. Any other ends or purposes that go beyond the protection of this desire are interpreted as being unnecessary and illegitimate demands on individual existence. That is why modern democratic man affirms his "independence" against the political order. "Humanitarian" politics, with its exclusive emphasis on equality and rights, is a kind of politics that wants to make the political disappear ${ }^{56}$. The contractarian variant of liberalism, both the old and the new, is oblivious of the fact that it is not the agreement of individual wills that generates society. In fact, any agreement of individual wills presuppose the existence of society, of something common in which human beings develop the necessary abilities and habits for agreements to occur. And contractarian liberalism avoids the question of knowing where the objects of agreement come from. Society, understood as a common historical space where the contents of life gain substance and consistence, is essentially the living together of men who relate to each other through speech, and who make this living together a subject of their speech. Aron thought that particularly in Europe this apolitical conception of democratic society was reaching a very dangerous point. "Europe must remember that individuals in a democracy are at once private persons and citizens", and that "our civilization, to the extent that it is a liberal one, is a citizen's society and not simply one of consumers or producers" 57 . Before the Second World War, Aron wrote that Europe "recognizes the particularities of expressive creations and of individual existences, at the moment when it threatens to destroy unique values" ${ }^{\prime \prime 5}$. Aron showed

56 Pierre Manent, Cours Familier de Philosophie Politique, (Paris: Fayard, 2001), pp. 227, 335-336.

57 Thinking Politically, p. 248.

58 Quoted in Memoirs, p. 81. 
us that this problem is not accidental. It is derived from a certain conception of human life, including political life, congenial to Europe's temper. But he also demonstrated that this problem is not a historically neutral question; it is a threat to some of Europe's most precious goods.

As Aron saw it, the West at the beginning of the 1980's faced a most subtle challenge: the "danger" came, not so much from the "totalitarian temptation", but rather from the "exorbitance of liberal ambitions", and the "impetuosity of egalitarian demands" ${ }^{\prime \prime}$. The problem was (and is) both political and intellectual. For political thought that rests exclusively on the concern with equality and rights is really not political thought; for it is a way of thinking which avoids the political, and examines individual existence without concern for individuals' relations to each other. Most importantly for our purposes here, this way of thinking is a way to avoid facing danger. It constructs an ideal of "citizenship" (conceding that the word makes sense in this context) that abstracts from the political conditions of human existence and wants to make this abstraction a concrete reality. It is a way of thinking that forbids the question concerning danger. Aron would never forget what his former teacher, Léon Brunschvicg, had told him: "Fortunately my political opinions have no consequences". In these words, Aron read a symptom of weakness, or maybe even of intellectual duplicity. To Aron there was no alternative: "it is easy to think about politics, but on one condition: recognition of and submission to its rules" ${ }^{\prime 60}$.

59 In Defense of Decadent Europe, note H, p. 284.

60 Memoirs, p. 96. 